\title{
Multi-risk quantitative assessment in Reghin city, Transylvania, Romania
}

\author{
Sanda ROȘCA ${ }^{1 *}$, Ștefan BILAȘCO ${ }^{1,2}$, Iuliu VESCAN ${ }^{1}$, Ioan FODOREAN ${ }^{1}$, Dănuț PETREA ${ }^{1}$, Raularian \\ RUSU $^{1}$
}

${ }^{1}$ Faculty of Geography, Babeș-Bolyai University, 5-7 Clinicilor Street, 400006 Cluj-Napoca, Romania

${ }^{2}$ Cluj-Napoca Subsidiary Geography Section, Romanian Academy, 400015 Cluj-Napoca, Romania

Received 21 November 2019; Revised 3 December 2019; Accepted 3 December 2019

*Correspondence to: Sanda ROȘCA e-mail: sanda.rosca@ubbcluj.ro

\begin{abstract}
Multi-risk assessment supposes an integrated analysis of various processes and phenomena generating risks across the territory, highlighting the individual and cumulative impact at different levels of analysis. This paper aims at creating an assessment model of multi-risk generated by the cumulative effects of landslides and floods, processes considered as significant in the study area, the administrative unit of the city of Reghin in the Transylvanian Basin. To obtain the multi-risk, two GIS spatial analysis models have been created. The first model means to identify the probability of landslide occurrence (built on GIS databases in vector and raster format, correlatively analysed by means of spatial analysis functions and equations), and is adapted according to legislative regulations stipulated in the Government Decision no. 447/2003. The second one is a database regarding the floodable area with a $1 \%$ probability in raster format, resulted from a nation-wide model created to identify the flooded areas. The multi-risk map was created using the mediation method, in which every class of individual (geomorphological or hydrological) hazard receives equal weight within the final result. As a consequence of applying the abovementioned models, we obtained areas with different probabilities for cumulative risk processes, which are rendered as favourable or restrictive in terms of locating different structures (roads, settlements, functional areas, shopping centres). According to the degree of validation, these may be used for a more precise determination of the development areas and for territorial planning.
\end{abstract}

KEYWORDS

multi-risk; G.I.S.; landslide; floodable areas; territorial planning 


\section{Introduction}

At regional level, integrated predictive models of sustainable territorial development, created according to the spatial analysis of resources, vulnerabilities and opportunities, are nowadays used in the studies concerning sustainable territorial development (Filip, 2009).

In order to achieve this, many studies and reports that have a strategic or programmatic nature are currently carried out, such as General Urban Plans (PUG), Zoning Plans (PATZ), regional and local development strategies and so on. Most of them have several substantial common shortcomings: the majority start from desirable subjective goals which are not consistent with the local and regional territorial opportunities; the insufficient and inexact quantitative data needed for a deeper knowledge of the defining states of a territory that is impacted, in the last years, by an unprecedented urban pressure (Benedek, 2016); and the almost total absence of an integrated multidisciplinary vision provided by a large range of specialists, obtained by the interconnection and synergic exploration of data and preliminary conclusions within an integrated model able to respond to the real fundament of the planning decision act to the benefit of all actors and factors involved in the complex process of territorial dynamics.

In order to highlight the punctual impact of the different integrating elements of risk, several initial vulnerability assessment models have been derived, both from the point of view of extreme hydrological processes (flash floods and floods) and of landslides, which have the main impact on continuously expanding urban areas (Ianoș, 1987).

The integrated approach of the two processes generating vulnerability for risk identification is less used in the process of assessment and diagnosis of territories for the provision of feasibility studies, while it is more often found in the applied research studies carried out to underlie impact studies (Micu et al., 2016).

In order to reduce the cumulated risks on a territory, it is necessary to integrate some methodological concepts to assess multi-hazard and multirisk (UNISDR, 2015), starting from the traditional individual approach for each risk to approaches identifying the complex interactions between risks (Gallina et al., 2016). The issue of modelling innovative approaches regarding multi-risk assessment has been raised in different recent studies, starting from the identification of common causes for the occurrence of different risk processes, to the necessity of quantitative assessment of the elements exposed to risks identified across the territory and the identification of cross-components relations (Terzi, 2019). Landslides and floods have a common triggering factor, the excessive amount of rainfall, higher than a certain threshold, concerning the river transport capacity in the case of floods, and the slope degree of stability in the case of landslides. Therefore, there is a cumulated effect of landslides and floods, involving a need for a cumulated analysis of these risks due to their cascade effect and the higher temporal and spatial probability for the values to exceed such thresholds (Gill, Malamud, 2016; Jurgilevich et al., 2017).

The unprecedented urban development registered in Romania in the last decades has been chaotically performed (Sestras et al., 2019), according to the wish of the private owners and developers, expanding housing development in such ways that one may identify parts of neighbourhoods or even full neighbourhoods subject to the risk induced by landslides and floods (Cocean et al., 2004). This situation leads to significant financial efforts to be made by the local public authorities to diminish the impact and reduce the associated risks. Such cases could have been avoided if the local public authorities, responsible for the planning issues within the administrative units, had practiced a sustainable territorial planning based on pre-feasibility and feasibility studies oriented towards the probable risks in the territories proposed for development (housing estates, transport and communication infrastructure, other facilities).

This study provides a GIS spatial analysis integrated model based on the derivation and modelling of databases needed for model structuring. It also presents the concept of database integration into a complex spatial analysis model for the assessment of cumulative risk induced in the territory by the two main vulnerabilities (floods and landslides) which have a visible impact in the study area. The 
model has in its centre the overlay type analysis of the main components, based on the principle of equal importance in terms of the risk classes impact on the territory, quantified by cumulating the punctual value of the impact assessed at the same scale on the basis of qualitative scores.

Under these conditions, the cumulated analysis of natural hazards becomes necessary, as well as a higher detailing degree of the database used and the use of a method involving the statistical analysis of the distribution, requirements meant to make possible the identification of the degree of influence of the factors included in the modelling of the analysed process or phenomenon (Bilașco et al., 2017).

\section{Study Area}

The city of Reghin is located in the hilly Reghin Basin, near the confluence of Mureș and Gurghiu rivers, in the central-northern part of Mureș County (Fig. 1). The administrative unit of Reghin municipality covers an area of about 5658 ha and is located on the Mureș River floodplain and terraces, but also on the lower and middle sectors of Reghin Hills (Conțiu, 2005). Most of this area provides favourable conditions for the building of housing estates and infrastructure elements. The present landscape, a tableland strongly fragmented by valleys, corridors and watersheds, landslides and powerful torrential erosion, is the consequence of the relatively recent morphological evolution in clays and marls, with some Helvetian sandstone layers (Ciocârdel, 1949).

The administrative territory of Reghin municipality is characterised by a small altitude range, of only $171 \mathrm{~m}$, as the lowest height, $337 \mathrm{~m}$, is recorded in the Mures floodplain, while the highest point is located in Reghin Hills at an altitude of $508 \mathrm{~m}$. The low floodplain area (at a height of 337-350 m) covers $8.4 \%$ of the territory ( 476.6 hectares), while the floodplain terraces (at a height of 350.1-370 m) cover $35.6 \%$ of the administrative unit (2014.5 hectares). Both are subject to the risk of flash floods and floods.

The current trend to locate residential areas as far away as possible from the city centre is also pre- sent in the case of Reghin municipality, where buildings are migrating towards the area located far from the centre, in the low hills $(401-500 \mathrm{~m})$, which cover $35.2 \%$ of Reghin administrative territory. This area is characterised by relatively steep slopes and geological features favourable to landslide processes if the slopes are overcharged (Irimus, and Szilágyi, 2017). The necessity for the existence of a multi-risk assessment carried out at least at national level has been stipulated at European level since 2009 (Marzochi et al., 2009).

\section{Methodology and Database}

GIS spatial modelling has the main goal to identify the possible ways in which processes become manifest on the basis of known facts about them or similarities with other resembling processes by means of the integrated analysis of the components using expert knowledge and cause-effect methods (Sestraș et al., 2019).

The proposed methodology to reach the final research objective is structured according to the requirements of GIS spatial analysis model, substantiated on databases, the study of relations between them and their inclusion in three stages to define the final model (Table 1). Each stage marks the creation of a spatial analysis submodel which, interconnected with the other submodels, leads to the identification of the cumulated risk across the territory. One remarks the last stage, concerning the proper risk assessment in the territory by means of an integrated analysis of the raster format database representing the cumulated vulnerability to landslides and floods with the vector format database representing housing estates and transport infrastructures on the basis of vector-raster overlay in order to achieve average vulnerability values per infrastructure unit, therefore identifying the weight of loss resulting from the two cumulated processes. The proper assessment and ranking of the factors involved in modelling represents an important stage in the models that determine the probability of landslide occurrence (Carrara et al., 1992; Guzzetti et al., 1999; Zezere et al., 2004; Van Western et al., 2006; Petrea et al., 2014; Roșca et al., 2015). 

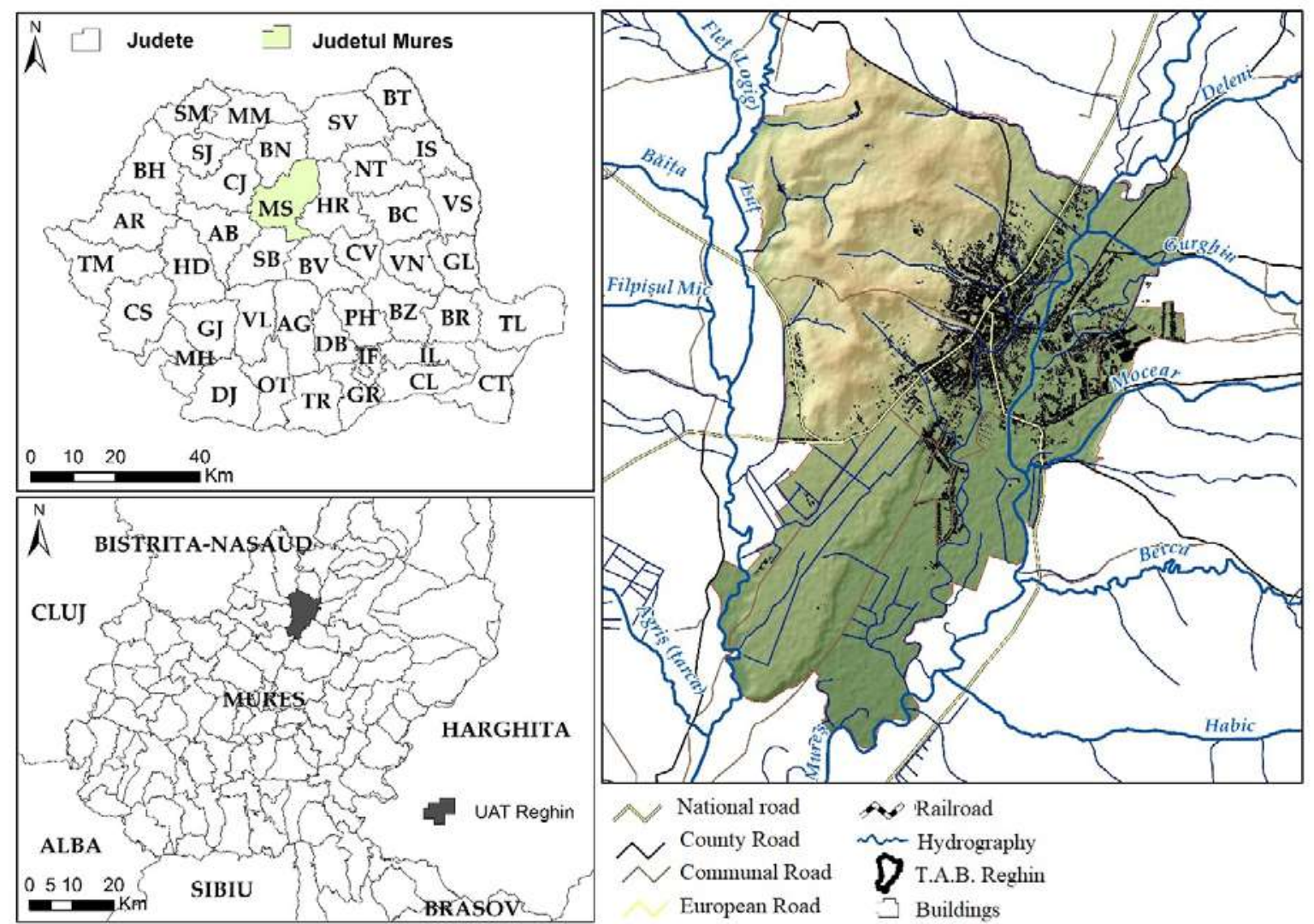

Figure 1 Geographical position of the study area

In this case, in order to achieve this database, a GIS spatial analysis model has been developed, according to the methodology imposed by the Romanian legislation (Government Decision no. 447/2003) regarding the technical and methodological standards for the mapping of landslides. In terms of floods, we used the floodable stripes of $1 \%$ probability of occurrence according to the legislation in force, achieved through vectorization from the cartographic database in analogous format concerning the floodable areas, mapped by INHGA (according to the Flood Risk Management Plan issued by the Mureș Water Catchment Administration).

\section{Multi-Risk G.I.S. based Assessment}

The spatial database acquisition represents the fundament of any integrated and multidisciplinary spatial analysis model. The high amount of data needed for the implementation of a spatial analysis model that is correct and valid from the point of view of the final results makes that the human component involved in their acquisition and processing to come from different research fields, which do not exclude each other, but interfere even more in their research area.

\subsection{Landslides Probability}

The geomorphological risk is induced in the territory of Reghin administrative unit by the presence of landslides. They are either active or have a potential to reactivate, and there is a probability of their occurrence as a result of morphological features and the changes emerged on the average and steep slopes due to construction works and vibrations produced by transport. Also, the state of balance of the slopes has been affected due to the accumulation of large amounts of water as a result of rainfall, but also due to leaks in the underground water supply pipes.

Generally, the landslide risk and the proposals for solutions regarding its mitigation are found in the fifth section of the National Master Plan (Law 
no. 575 on the 22nd of October 2001). The definition of classes for geomorphological risks is found in the Government Decision no. 447/2003, where one finds Methodological norms regarding the manner of achievement and the contents of natural risk maps concerning landslides. These norms stipulate the classification of the probability of landslide occurrence by providing influence scores to the factors causing and triggering landslides, such as geology, geomorphological features (slope and altitude), as well as structural, hydro-climatic, hydrogeological, seismic, forestry and anthropogenic features (Figs. 2-9).

Table 1 Database structure

\begin{tabular}{|c|c|c|c|c|c|c|}
\hline No. & Database name & Type & Structure & Attribute & Origin & $\begin{array}{l}\text { Modelling } \\
\text { level }\end{array}$ \\
\hline 1 & Hypsometry & Raster & GRID & Altitude (m) & Primary & \\
\hline 2 & Slope & Raster & GRID & Slope angle (\%) & Modelled & \\
\hline 3 & Aspect & Raster & GRID & Aspect (8 direction) & Modelled & \\
\hline \multirow[t]{2}{*}{4} & Geology & Vector & Polygon & Geology classes & Digitised & \\
\hline & & Raster & GRID & $\mathrm{Ka}$ & Derived & \\
\hline 5 & Precipitation Grid & Raster & GRID & $\begin{array}{l}\text { Precipitation } \quad \text { average } \\
\text { value }(\mathrm{mm})\end{array}$ & Modelled & \\
\hline \multirow[t]{2}{*}{6} & Hydrogeological & Vector & Polygon & Value & Digitised & \\
\hline & classes & Raster & GRID & $\mathrm{Ke}$ & Derived & \\
\hline \multirow[t]{2}{*}{7} & Seismic coefficient & Vector & Polygon & Value & Digitised & \\
\hline & & Raster & GRID & $\mathrm{Kf}$ & Derived & \\
\hline \multirow[t]{2}{*}{8} & Forestry & Vector & Polygon & Land-use classes & Digitised & \\
\hline & coefficient & Raster & GRID & $\mathrm{Kg}$ & Derived & ニ \\
\hline \multirow[t]{2}{*}{9} & Anthropogenic & Vector & Polygon & Value & Digitised & ” \\
\hline & coefficient & Raster & GRID & $\mathrm{Kh}$ & Derived & $\frac{0}{\bar{n}}$ \\
\hline 10 & $\begin{array}{l}\text { Landslide } \\
\text { probability }\end{array}$ & Raster & GRID & Value $(0-0.45)$ & Modelled & 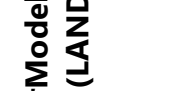 \\
\hline \multirow[t]{2}{*}{11} & Floodable stripes & Raster & GRID & $1 \%$ & Digitised & ํํำ \\
\hline & & Vector & Polygon & & Derived & 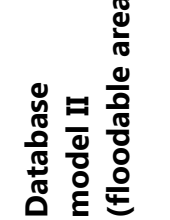 \\
\hline 12 & $\begin{array}{l}\text { Landslide } \\
\text { probability }\end{array}$ & Raster & GRID & Value $(0-0.45)$ & Modelled & \\
\hline 13 & Floodable stripes & Raster & GRID & - & Derived & \\
\hline 14 & Vulnerability & Raster & GRID & $\begin{array}{l}\text { Surface of cumulative } \\
\text { probability / }\end{array}$ & Modelled & \\
\hline & & & & landslide/floodable areas & & \\
\hline 15 & Exposure & Vector & Polygon & Surface/vulnerability & $\begin{array}{l}\text { Modelled } \\
\text { Statistical } \\
\text { Analysis }\end{array}$ & 罗 \\
\hline 16 & Risk & Raster & GRID & $\begin{array}{l}\text { Surface/vulnerability } \\
\text { /infrastructures }\end{array}$ & Derived & 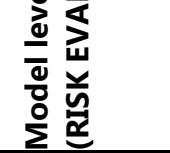 \\
\hline
\end{tabular}

In this case, the average hazard coefficient regarding landslides achieved as a result of applying the above-mentioned methodology is between 0 and 0.45 , corresponding to a class of low, average and average-high probability.
The class of average-high probability of landslide occurrence is identified with a value of the average hazard coefficient above 0.35 and is spatially located across an area of 3667.5 hectares $(65.57 \%$ of Reghin municipality area), generally in the middle 
sectors of Reghin Hills (Fig. 10), where there are slopes above 15 degrees and geological layers made of clays and marls, therefore increasing the probability of landslide occurrence and implicitly leading to a relative instability of these areas.

The class of average probability of landslide occurrence involves an average hazard coefficient between 0.15 and 0.35 and covers 1783.82 hectares, about $31.89 \%$ of Reghin municipality (Table 2). It characterizes the lower sectors of the medium and low hills, with slopes between 5 and 15 degrees, where there is a lower probability for landslides to occur. Such processes may take place as a result of reaching a high degree of wetness within the supporting clay layers, either as a consequence of heavy rainfall amounts or because of earthquakes able to destabilize the initial balance.

The class of low probability of landslide occurrence covers only $2.53 \%$ of Reghin municipality territory, and is characteristic for the tops of Mures terraces and its floodplain. The morphometric and morphographic features provide stability from the point of view of landslides. However, some of these areas are prone to the risk of flooding.

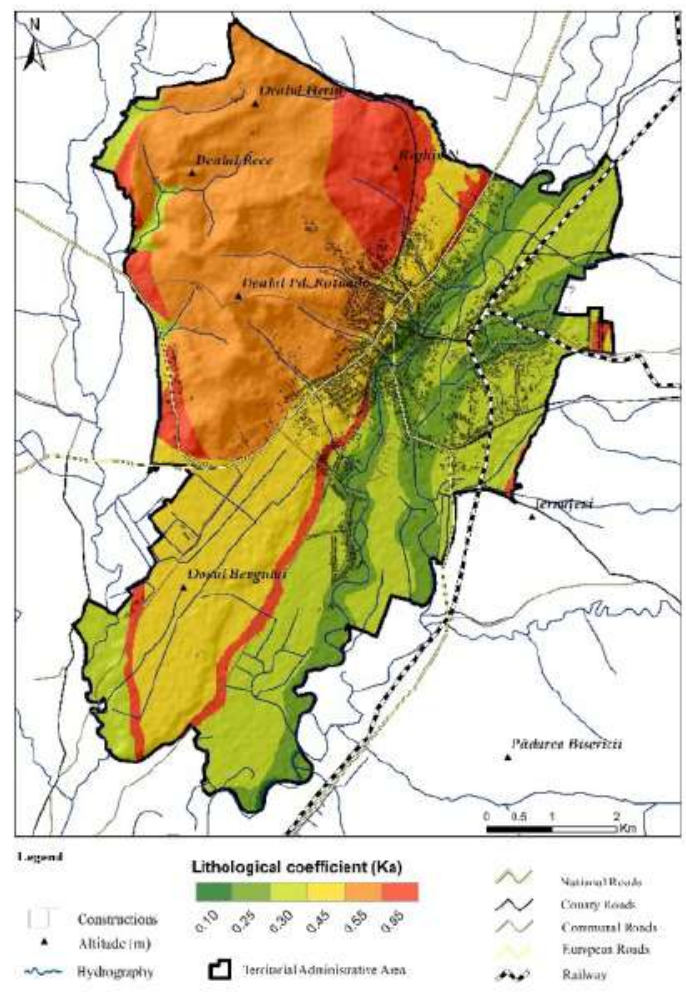

Figure 2 Map of Lithological coefficient

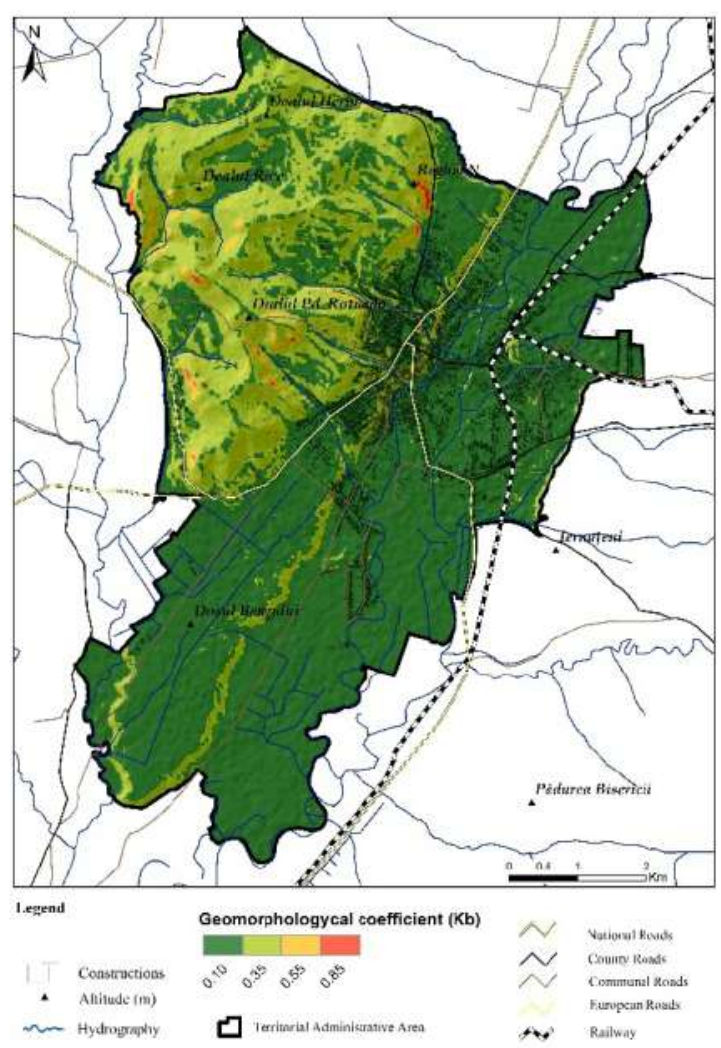

Figure 3 Map of Geomorphological coefficient

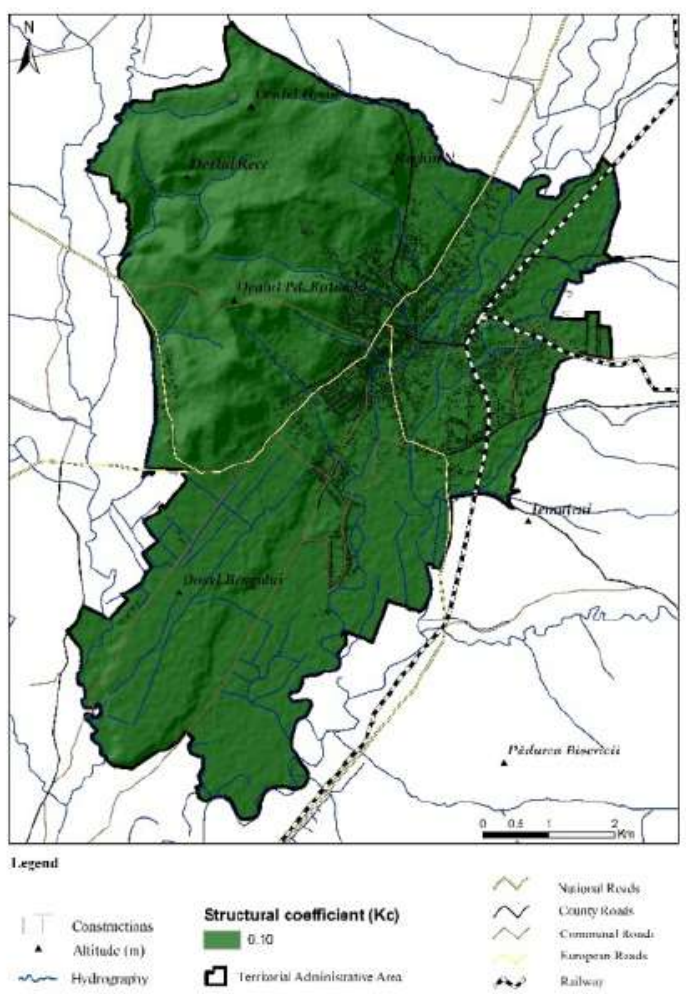

Figure 4 Map of Structural coefficient 


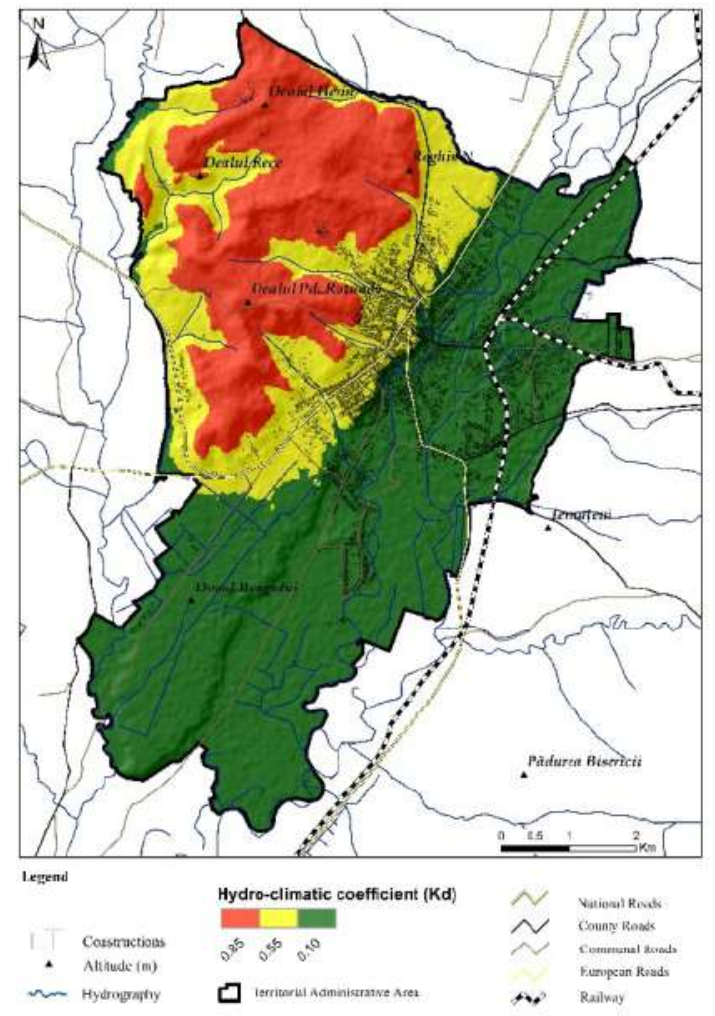

Figure 5 Map of Hydro-climatic coefficient

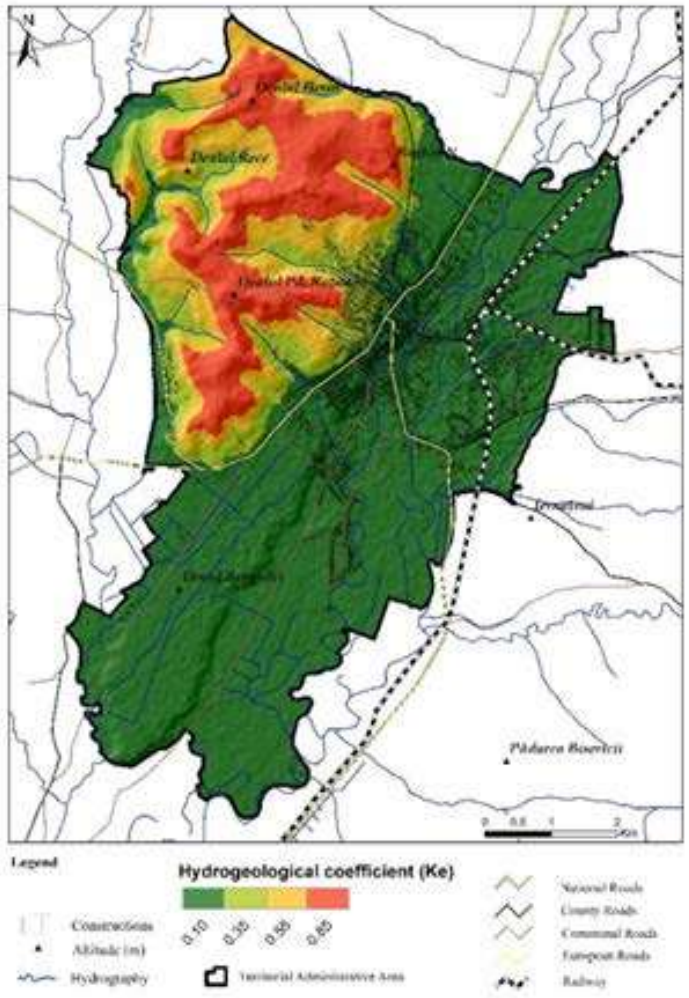

Figure 6 Map of Hydrogeological coefficient

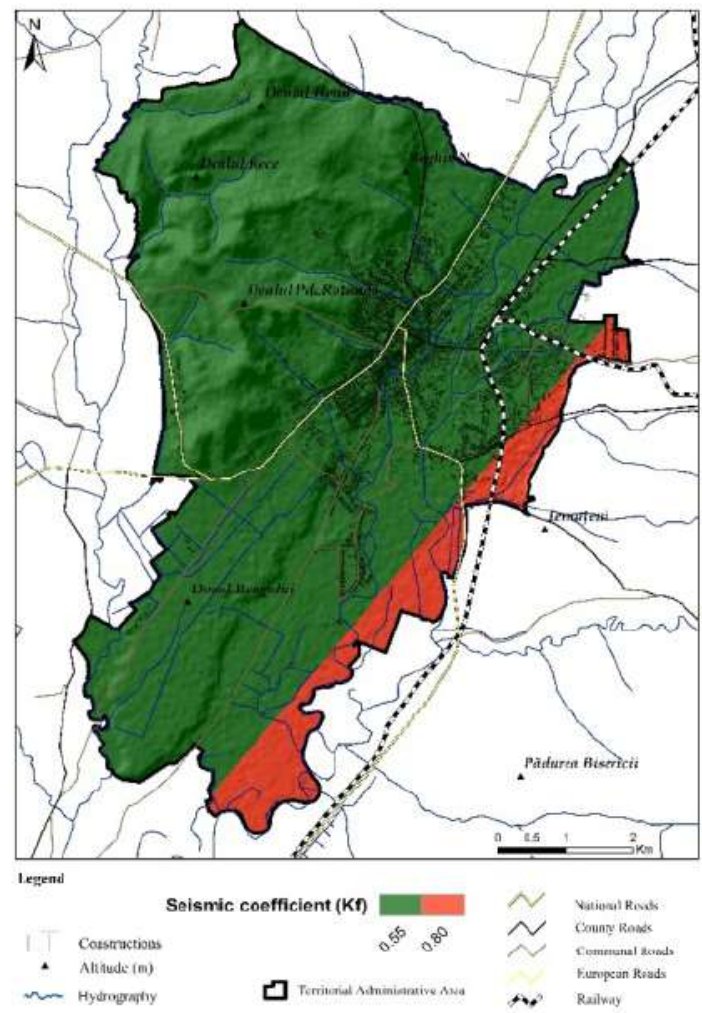

Figure 7 Map of Seismic coefficient

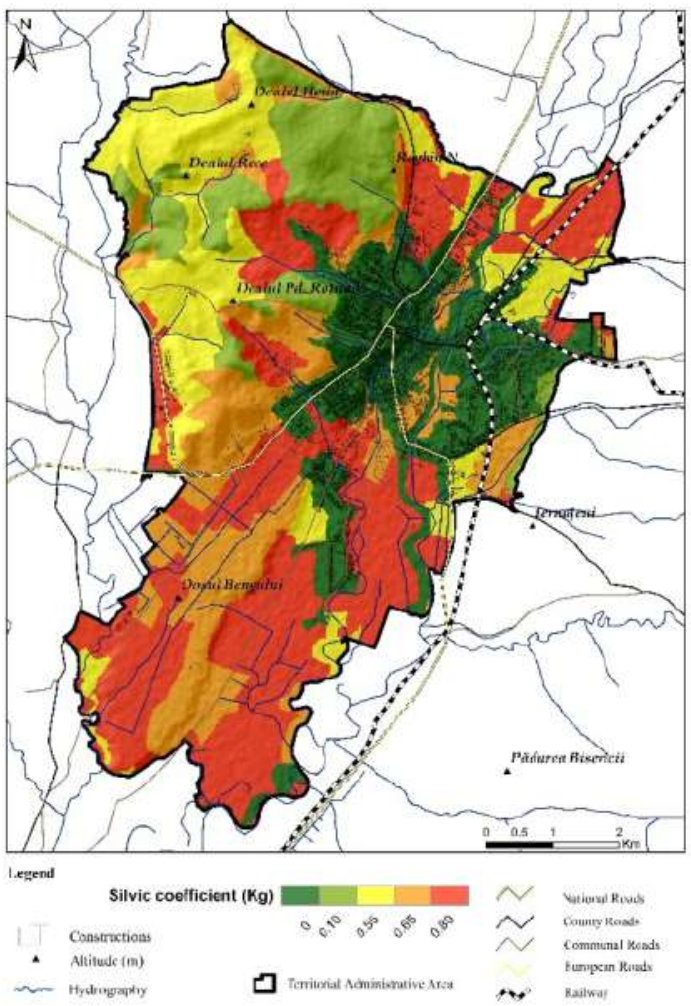

Figure 8 Map of Forestry coefficient 


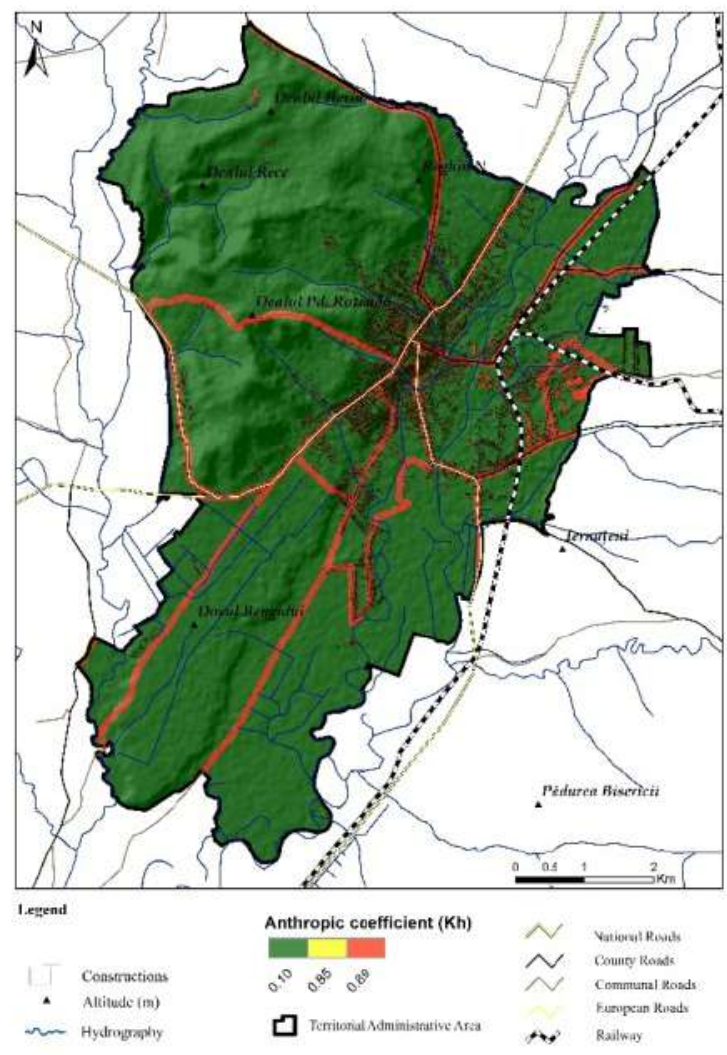

Figure 9 Map of Anthropogenic coefficient

Regarding the damages that might occur as a result of landslides across the territory of Reghin municipality, the value of material damage and loss of human life associated directly with the landslides has been estimated, where the risk is defined as a product of the landslide occurrence probability expressed by the hazard average coefficient $(\mathrm{Km})$ and the value of material damage (expressed by the totality of elements prone to landslide hazards).

\subsection{Flood Assessment}

For the administrative territory of Reghin municipality, the flood risk has been identified by assessing the elements prone to flooding. The floodable stripes mapped in the studies carried out by the Romanian Water Administration (Fig. 11) have been modelled as a spatial extension of the area to be flooded in case of reaching a maximum discharge with a $1 \%$ probability of exceeding, i.e. floods that may occur once in 100 years. Within the limits of the studied administrative unit, the floodable stripes cover an area of 633.76 hectares, and they are lo- cated relatively symmetrical on the two sides of Mures river bed. In case of reaching the maximum discharge, only small parts of Unirii, Topliței and Iernuțeni may be affected, considering that most of Mures river bed is confined by banks meant for defence against flooding.

However, there might be water overflows in the case of secondary tributaries, such as Trandafirilor brook or Bodogaia Valley. They have a less developed river bed and therefore a small capacity to transport water. When abundant rainfall occurs, there are local floods and the water pouring down the slopes may stagnate due to poor sewerage and the large area covered by buildings and asphalt.

Regarding flood risk assessment, Willems et al. (2003) proposed a matrical classification depending on land use categories and their exposure to flooding. According to it, grasslands, meadows, forested areas and deforested shrub areas, are included in the exposure class 0 . Fields covered by orchards, vineyards, as well as agricultural lands mixed with natural vegetation are included in the exposure class 1 . The residential urban and rural areas are included in the exposure class 2, while transport infrastructure elements (roads, railways), industrial and commercial units are included in the exposure class 3 (Table 3 ).

\subsection{Multi-Risk Assessment}

The mapping of risks for the current geomorphological processes represents a necessity in the territorial planning proposals (Carrara et al., 1999). For this purpose, there are several methods involving the use of GIS technology, statistical methods to determine the spatial occurrence probability (Guzzetti et al., 1999), quantitative-probabilistic methods (Coe et al., 2004; Polemio and Petrucci, 2010) and qualitative methods (Latelin, 1997). There are also matrical assessments of classifying the territory according to risk classes, which highlight the relations established between susceptibility classes (the landslide occurrence probability) and the potential damage that may result if they are triggered.

In order to identify the geomorphological risk, the elements of the built-up area have been overlapped with the raster of the average hazard coefficient calculated according to the methodological 
regulations stipulated in the Government Decision no. 447/2003, which presents the stages needed to perform a risk study to mitigate the negative effects of landslides. Concerning floods, one may highlight clearly the high risks caused by them in the territory, as about $14.54 \%$ of the buildings are in this risk category. This fact is explained by the location of Reghin built-up area, very close and along the main stream that causes the risk, Mureș River. The same thing is true for the transport infrastructure (roads and railways), of which $25 \%$ are in this risk category.
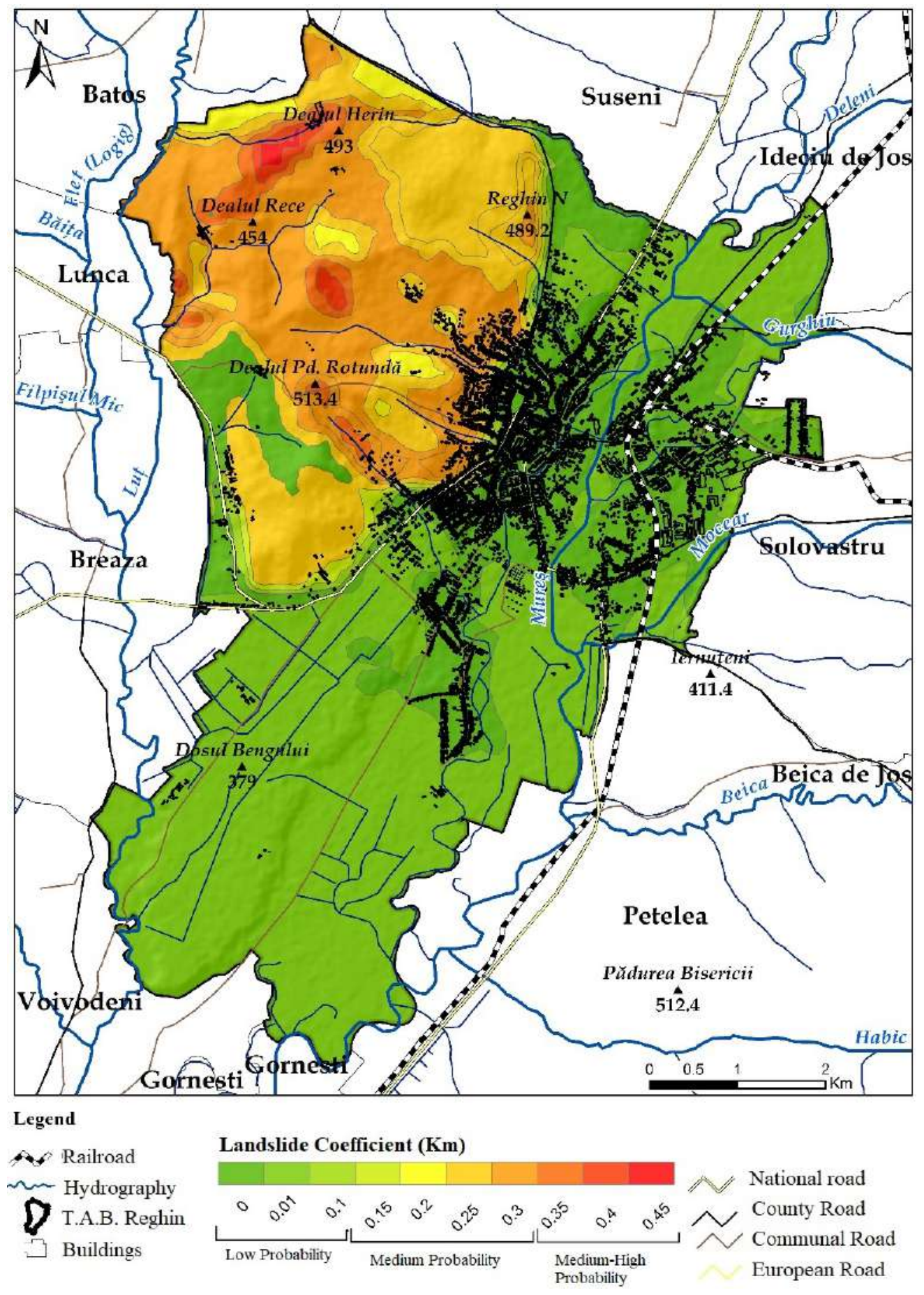

National road County Road Communal Road European Road

Figure 10 Map of geomorphological risk in Reghin municipality 
ROȘCA et al. / Revista de Geomorfologie 21 (2019)

Table 2 Territorial distribution of classes regarding landslide occurrence probability

\begin{tabular}{ccccc}
\hline Nr. & $\begin{array}{c}\text { Hazard average } \\
\text { coefficient } \mathbf{( K m})\end{array}$ & Probability class & Area & ha \\
\hline $\mathbf{1}$ & 0.5 & Average-high probability & 0.20 & 0.00 \\
$\mathbf{2}$ & 0.45 & & 1375.51 & 24.59 \\
$\mathbf{3}$ & 0.4 & Average probability & 2291.85 & 40.98 \\
\hline $\mathbf{4}$ & 0.35 & & 70.89 & 1.27 \\
$\mathbf{5}$ & 0.3 & & 58.90 & 1.05 \\
$\mathbf{6}$ & 0.25 & & 75.74 & 1.35 \\
$\mathbf{7}$ & 0.20 & Low probability & 733.16 & 13.11 \\
$\mathbf{8}$ & 0.15 & & 845.13 & 15.11 \\
$\mathbf{9}$ & 0.1 & 97.58 & 1.74 \\
$\mathbf{1 0}$ & 0.01 & 35.33 & 0.63 \\
$\mathbf{1 1}$ & 0 & & 8.73 & 0.16 \\
\hline
\end{tabular}

Table 3 Distribution of land use classes according to exposure to risk

\begin{tabular}{ccccc}
\hline & \multicolumn{5}{c}{ Flood exposure classes } \\
\cline { 2 - 5 } Area $\left(\mathbf{k m}^{2}\right)$ & $E 0$ & $E 1$ & $E 2$ & $E 3$ \\
\cline { 2 - 5 } & 0.2 & 3.6 & 1.7 & 0.93 \\
\hline
\end{tabular}

In the study area represented by Reghin municipality, one remarks that $0.43 \%$ of the buildings (46 buildings) in the city of Reghin are located in the area with a high probability of landslide occurrence and $14.54 \%$ (1345 buildings) in the area prone to flood risk (Table 4).

The identification of areas that are favourable or restrictive in terms of the location of housing estates and transport infrastructures is vital for a proper territorial planning. It has been achieved by creating a model which integrates by means of mediation (EPA, 2003) the databases used for the individual risk assessment. There is also the possibility to achieve the multi-risk map by using the maximization method, but in this case there is an overestimation of the cumulated risk (Roșca, 2015).

In order to bring the databases at the same scale of values in terms of territorial impact, the standard interval from 1 to 4 has been chosen for landslide risk classes, where 1 corresponds to the class of practically no risk, and 4 to a high risk of landslide occurrence. For the flood risk, the standard value 1 corresponds to areas without any chance of flooding and 4 to areas that may be flooded once every 100 years, so there is a high flood risk (Fig. 12).

The spatial assessment to identify the multi-risk is based on the spatial analysis of attribute tables by means of spatial analysis equations based in their turn on mathematical identifiers that integrate the numerical information stored within the attribute table. In the final model, the two analysed databases, the landslide risk and the flood risk, are managed as vectoral databases, the landslide risk obtained by converting the raster qualitatively scored from 1 to 4 , and the flood risk by spatially merging the floodable stripes and the administrative unit of the study area, as well as by adding the specific qualitative scores in the attribute table.

Table 4 Classification of residential and transport infrastructure according to landslide and flood risk classes

\begin{tabular}{lrrrrrr}
\hline \multirow{2}{*}{ Exposed elements } & \multicolumn{3}{c}{ Landslide risk } & \multicolumn{3}{c}{ Flood risk } \\
& Practically zero & \multicolumn{1}{c}{ Low } & Medium & High & Practically zero & High \\
\cline { 2 - 7 } Buildings (\%) & 67.12 & 17.98 & 14.46 & 0.43 & 85.46 & 14.54 \\
Roads (\%) & 51.75 & 35.87 & 11.92 & 0.46 & 81.87 & 18.13 \\
Railways (\%) & 68.50 & 31.50 & 0.00 & 0.00 & 93.06 & 6.94 \\
\hline
\end{tabular}




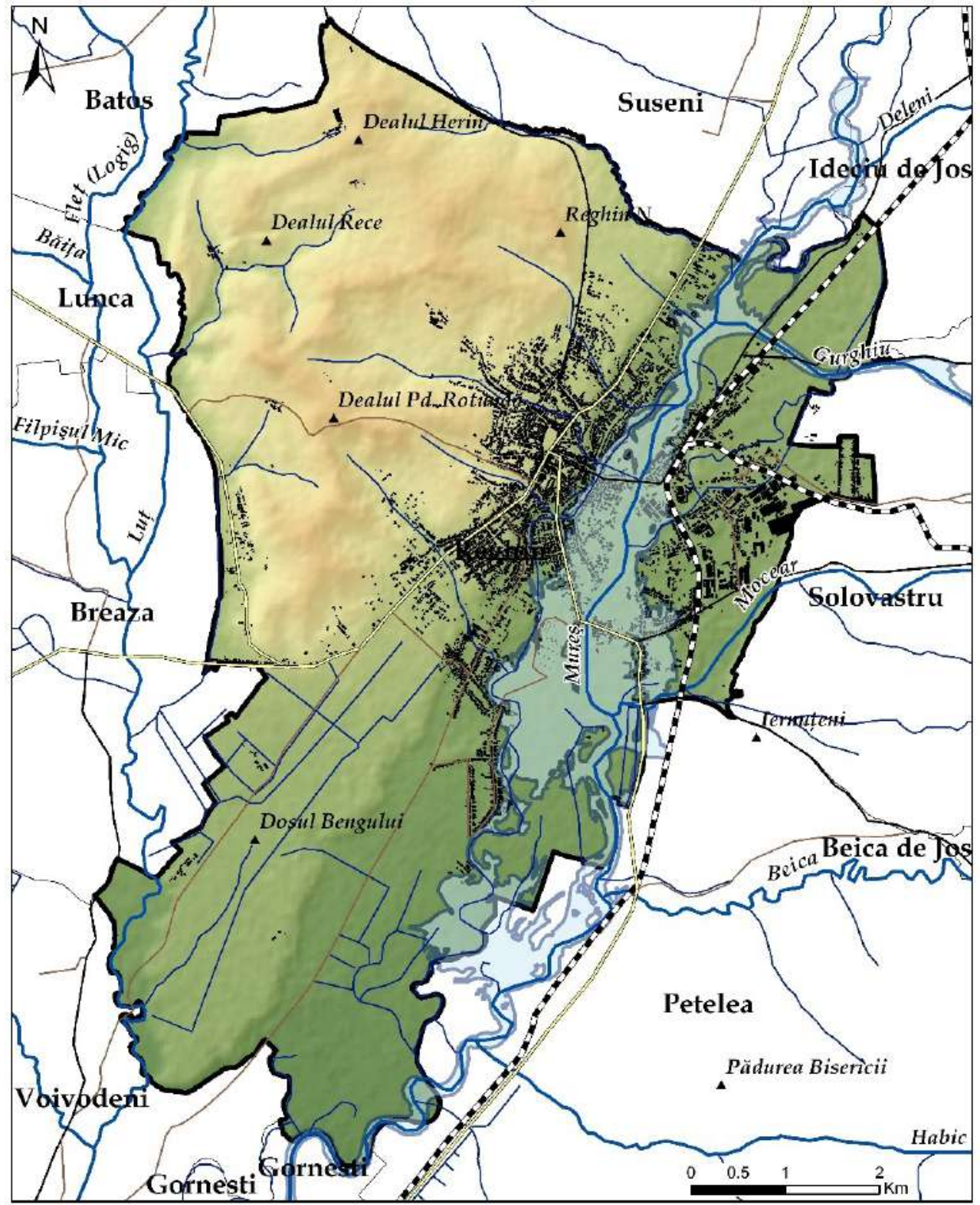

Legenda

(1) Flood stripes $1 \%$

- Altitude

National road County Road

Communal Road European Road

1 T.A.B. Reghin
Buildings

Figure 11 Flood map

The integration of polygon-type vectoral databases supposed the use of identify function to obtain a polygon-type spatial database including attribute information that is spatially identified correctly from the point of view of the risk it represents across the territory. Therefore, two new columns were obtained in the attribute table, each of them storing information concerning the individual risk class for a certain area. The spatial analysis equation was applied to cumulate the corresponding values in the attribute table for every area, on the basis of the mathematical identifier sum and equal weight, which allowed the risk to be cumulated and stored as a numerical score information in a new column in the attribute table. This column represents the value of the risk impact on the territory and includes values between 1 and 4 . 


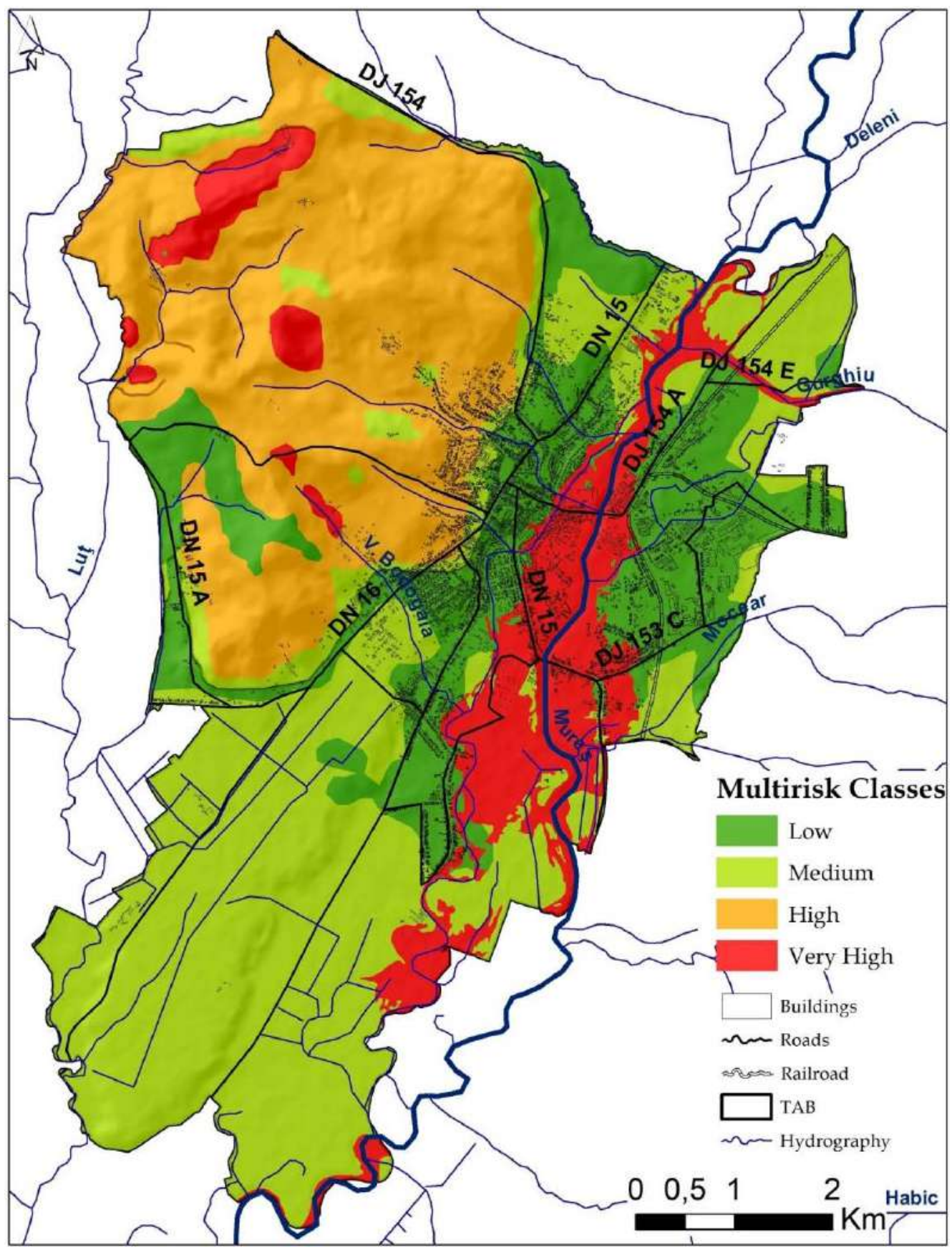

Figure 12 Multi-risk assessments in Reghin municipality

\section{Conclusions}

The analysed territory, corresponding to the City of Reghin administrative area, is affected by landslides along the slopes. The residential areas and the transport infrastructure located in areas prone to landslides are at risk due to the overcharging of slopes with buildings and the existing favourable conditions for the landslide processes to become manifest. To these geomorphological risk phenomena, one may add the high density of constructions along the Mures river bed, which brings into discussion the flood risk in the context of increasing discharges, exceeding the danger level. It is therefore necessary to perform a multi-risk type analysis to highlight the areas exposed to risk-generating processes in order to reduce or eliminate the material damage and the potential loss of human life. 
As a result of applying the GIS spatial analysis techniques, the probability of landslide occurrence has been identified according to the methodological norms established by the Government Decision no. $447 / 2003$, which lays stress on the causing and triggering factors at national level. Accordingly, there are large areas across Reghin municipality characterised by an average-high probability of landslide occurrence. At the level of these areas, detailed geotechnical studies are needed to mitigate the negative effects, laying the basis for specific drainage works and for the decrease in the number of building certificates issued by the authorities for new constructions on the slopes characterised by instability.

The flood risk for a discharge with a $1 \%$ probability of occurrence is significant for $11.31 \%$ of the Reghin administrative area, endangering a number of 1345 buildings, $5.52 \mathrm{~km}$ of roads and $0.52 \mathrm{~km}$ of railways. The presented model highlights a useful method to identify the degree of territorial functionality of parts of the built-up areas where risk studies are needed to be performed for detailed urban plans that have the main purpose of planning the areas and delineating functional zones such as the category of residential areas proposed for development and areas proposed for industrial development. The areas proposed for the development of transport infrastructure and services are tightly linked to the previous ones, as the infrastructure is highly sensitive to the landslide and flood risks, which may determine the danger of accidents in case that the infrastructure is developed in improper areas from the point of view of the impact.

The multi-risk type assessment, performed by the method of mediation, led to the multi-risk map, where each individual risk class received an equal weight in the final result. As such, the very high multi-risk class highlights the presence of residential buildings and transport infrastructure in the areas with the highest probability of landslide or flood occurrence. In these areas, it is strongly recommended not to build anymore, to create events to inform the inhabitants about the risks they are exposed to and to make structural decisions to mitigate the potential negative effects.

\section{Acknowledgements}

The present work has received financial support through the project: Entrepreneurship for innovation through doctoral and postdoctoral research, POCU/360/6/13/123886 co-financed by the European Social Fund, through the Operational Program for Human Capital 2014-2020. All authors have equal contribution to this paper.

\section{References}

*** Government Decision no. 447 of April 10, 2003, concerning the approval of the methodological rules related to the drafting and content of the natural hazard maps regarding floods and landslides, published in Monitorul Oficial, May 7, 2003 (in Romanian).

*** Flood Risk Management Plan, Mureş Water Catchment Administration, available online:

http://www.inhga.ro/documents/10184/121027/3+P

MRI+Mures.pdf/f5fd79d8-237d-4ced-ab11e883f6620825

*** EPA 2003. Report on the environment technical document, Unites States Environmental Protection Agency, Washington.

*** UNISDR. 2015. Sendai Framework for Disaster Risk Reduction 2015-2030.

Benedek J. 2016. The role of urban growth poles in regional policy: the Romanian case. Procedia - Social and Behavioral Sciences, 223: 285-290.

Bilașco Şt, Roșca S, Fodorean I, Vescan I, Filip S, Petrea D. 2018. Quantitative evaluation of the risk induced by dominant geomorphological processes on different land uses, based on GIS spatial analysis models. Front. Earth Sci., 12(2): 311-324. https://doi.org/10.1007/s11707-017-0679-3.

Carrara A, Cardinali M, Guzzetti F. 1992. Uncertainty in assessing landslide hazard and risk. ITC J, 2: 172-183.

Carrara A. et al., 1999. Use of GIS Technology in the Prediction and Monitoring of Landslide Hazard. Natural Hazard, 20: 117-135.

Ciocârdel R. 1949. Geologia regiunii Bistrița-Reghin. Dări de seamă ale ședințelor, 37: 131-141.

Cocean P, Irimuş IA. et al. 2004. Planul de Amenajare a Teritoriului Regiunii de Nord-Vest, Editura Presa Universitară Clujeană, Cluj-Napoca.

Coe JA, Godt JW, Baum RL, Bucknam RC, Michael JA. 2004. Landslide Susceptibility from topography in Guatemala. In: Lacerda WA, Erlich M, Fontoura SAB, and Sayao ASF. (eds.): Landslides, evaluation and stabilization. Proceedings of the 9th international Symposium on Landslide, Rio de Janeiro, 1: 69-79. 
Conţiu Hadrian-V, Conţiu A. 2005. Percepţia inundaţiilor în culoarul Mureşului dintre Reghin şi confluenţa $\mathrm{cu}$ Arieşul. In: Riscuri şi catastrofe, 4(2): 99-108.

Filip S. 2009. Planning urban. Presa Universitară Clujeană, Cluj-Napoca.

Gallina V, Torresan S, Critto A, Sperotto A, Glade T, Marcomini A. 2016. A review of multi-risk methodologies for natural hazards: consequences and challenges for a climate change impact assessment. J. Environ. Manag., 168: 123-132.

Gill JC, Malamud BD. 2017. Anthropogenic processes, natural hazards, and interactions in a multi-hazard framework. Earth Sci. Rev., 166: 246-269.

Guzzetti F, Carrara A, Cardinali M, Reichenbach P. 1999. Landslide hazard evaluation: a review of current techniques and their application in a multiscale study, Central Italy. Geomorphology, 31(1-4): 181-216.

Ianoș I. 1987. Orașele și organizarea spațiului geografic. Editura Academiei, București.

Irimuş IA, Szilágyi JM. 2017. Geomorphological hazards from the Reghin Hills with risk potential. In: Riscuri şi castastrofe, 16(20): 151-159.

Jurgilevich A, Räsänen A, Groundstroem F, Juhola S. 2017. A systematic review of dynamics in climate risk and vulnerability assessments. Environ. Res. Lett., 12. https://doi.org/10.1088/1748-9326/aa5508

Lateltin O. 1997. Berücksichtigung der Massenbewegungsgefahren-beiraumwirksamen Tätigkeiten. Empfehlungen, Swiss Federal Office for Water and Geology (FOWG).

http://www.bwg.admin.ch/themen/natur/e/index.htm

Marzocchi W, Mastellone M L, Di Ruocco, Novelli A, Romeo P, Gasparini P. 2009. Principle of multi-risk assessment, research performed in the frame of Na.R.As (Natural Risks Assessment) FP6 SSA Project No. 511264, Napoli, Italia.

Micu M, Jurchescu M, Șandric I, Mărgărint C, Chițu Z, Micu D, Ciurean R, Ilinca V, Vasile $M, 2016$. Mass movement. In: Rădoane M, Vespremeanu-Stroe A. (eds.): Landform Dynamics and Evolution in Romania. Springer Geography, Springer International Publishing Switzerland.

Petrea D, Bilașco Șt, Roșca S, Vescan I, Fodorean I. 2014. The determination of the Landslide occurrence prob- ability by spatial analysis of the Land Morphometric characteristics (case study: the Transylvanian Plateau). Carpath J Environ Sci, 9: 91-110.

Polemio M, Petrucci O. 2010. Occurrence of landslide events and the role of climate in the twentieth century in Calabria, southern Italy. Quarterly Journal of Engineering Geology and Hydrogeology, 43: 403415, DOI:10.1144/1470-9236/09-006.

Roșca S, Bilașco Ș, Petrea D, Fodorean I, Vescan I, Filip S. 2015. Application of landslide hazard scenarios at annual scale in the Niraj River basin (Transylvania Depression, Romania). Nat Hazards, 77: 1573-1592, DOI 10.1007/s11069-015-1665-2.

Roșca S. 2015. Bazinul Nirajului studiu de geomorfologie aplicată. Editura Risoprint, Cluj-Napoca.

Sestras P, Bilasco S, Rosca S, Nas S, Bondrea MV, Galgau R, Veres I, Salagean T, Spalevic V., Cimpeanu SM. 2019. Landslides Susceptibility Assessment Based on GIS Statistical Bivariate Analysis in the Hills Surrounding a Metropolitan Area. Sustainability, 11(5), DOI: $10.3390 /$ su 11051362 .

Terzi S, Torresan S, Schneiderbauer S, Critto A, Zebisch M, Marcomini A. 2019. Multi-risk assessment in mountain regions: A review of modelling approaches for climate change adaptation. Journal of Environmental Management, 232: 759-771. doi.org/10.1016/j.jenvman.2018.11.100.

Van Westen CJ, Van Asch TWJ, Soeters R. 2006. Landslide hazard and risk zonation - why is it still so difficult? Bull Eng Geol Environ, 65: 167-184. doi:10.1007/s10064-005-0023-0.

Willems P, Thompson S, Barbieri M. 2003. Flood risk and damage Assessment using Modelling and Earth observation techniques (FAME). Final Report, Data User Programme (DUP-2), ESA, $48 \mathrm{p}$. http://www.kuleuven.be/hydr/fame.htm.

Zezere JL, Rodrigues ML, Reis E, Garcia R, Oliveira S, Vieira G, Ferreira AB. 2004. Spatial and temporal data management for the probabilistic landslide hazard assessment considering landslide typology. In: Lacerda WA, Ehrlich M, Fontura SAB, Sayão ASF (eds.): Landslides: evaluation and stabilization. Taylor \& Francis Group, London, 117-123. 